\title{
The effect of thermal shock during diel vertical migration on the energy required for oceanic migration of the European silver eel
}

\author{
T. Trancart a, ${ }^{\mathrm{a}}$, C. Tudorache ${ }^{\mathrm{b}}$, G.E.E.J.M. van den Thillart ${ }^{\mathrm{b}}$, A. Acou ${ }^{\mathrm{a}, 1}$, A. Carpentier $^{\mathrm{c}}{ }^{\mathrm{C}}$ C. Boinet ${ }^{\mathrm{a}, 1}$, \\ G. Gouchet ${ }^{\mathrm{a}, 1}$, E. Feunteun ${ }^{\mathrm{a}, 1}$ \\ a French National Museum of Natural History, Marine Station Service, 38 rue du port blanc, UMR 7208, 35800 Dinard, France \\ b Molecular Cell Biology, Institute Biology Leiden, Leiden University, P.O. Box 9505, 2300 RA Leiden, The Netherlands \\ c University of Rennes 1, EA 7316, Campus de Beaulieu, 35042 Rennes cedex, France
}

\section{A R T I C L E I N F O}

\section{Article history:}

Received 18 July 2014

Received in revised form 2 December 2014

Accepted 8 December 2014

Available online 18 December 2014

\section{Keywords:}

Anguilla anguilla

Conservation physiology

Oxygen consumption

Swimming respirometry

Swimming tunnels

\begin{abstract}
A B S T R A C T
Recently, diel vertical migration (DVM) was observed in European silver eels (Anguilla anguilla) migrating towards the Sargasso Sea. However, because European silver eels do not feed during this migration, their energy consumption requires accurate optimization due to their limited fat reserves. In this study, changes in water temperature were experimentally induced to simulate those experienced by silver eels during DVMs to estimate their effect on oxygen consumption $\left(\mathrm{MO}_{2}\right)$. Therefore, the oxygen consumption of eels at $8{ }^{\circ} \mathrm{C}$ (deep waters) and $14^{\circ} \mathrm{C}$ (surface waters) was measured, and the effect of rapid thermal changes (shocks) from $8{ }^{\circ} \mathrm{C}$ to $14{ }^{\circ} \mathrm{C}$, simulating ascent, and from $14{ }^{\circ} \mathrm{C}$ to $8{ }^{\circ} \mathrm{C}$, simulating descent, both movements mimicking DVMs, were assessed. Firstly, a single thermal shock induced an increase in $\mathrm{MO}_{2}$ in both sexes at both temperatures.

Secondly, the cumulative effect of these two factors (single temperature and thermal shock) was analysed to mimic natural DVMs, and showed that an increase in $\mathrm{MO}_{2}$ was linked to DVMs in females ( $+16 \%$ at ascent, and $17.9 \%$ at descent $)$ and for males during DVM ascents $(+73.9 \%)$. These data are used to discuss the effect of DVMs on the cost of transport in European eels during their breeding migration across the Atlantic Ocean.
\end{abstract}

(c) 2014 Elsevier B.V. All rights reserved.

\section{Introduction}

The European eel (Anguilla anguilla) has a particular life cycle; they hatch in the Sargasso Sea and migrate to European coasts during the larval stage. After a growth stage in inland waters lasting 5-30 yr, the silver eels undertake a spawning migration of approximately $5000 \mathrm{~km}$ from Europe back to the Sargasso Sea (Tesch, 1977).

Aarestrup et al. (2009) showed that the European eel travels up to $50 \mathrm{~km}$ per day, and that they exhibit a consistent diel vertical migration (DVM), ascending to warmer shallower waters at dusk and descending into deeper, colder water at dawn, from 200 to $900 \mathrm{~m}$ and 14 to $8{ }^{\circ} \mathrm{C}$ every day over a short time period (i.e. $30 \mathrm{~min}$ ). This behaviour was confirmed in European eels by Wahlberg et al. (2014) who studied predation risks experienced by marine mammals using data collected during the Eeliad project. First described in Tesch (1989), no clear reasons were suggested for this behaviour, and the reasons of these DVMs remain unknown. Aarestrup et al. (2009) hypothesized that the DVMs reflect thermoregulation, and stated that the daily ascent into shallower warm water may serve to maintain sufficiently high metabolism (respiratory metabolism being considered as a proxy of the global

\footnotetext{
* Corresponding author. Tel.: + 33223185885 .

E-mail address: thomas.trancart@mnhn.fr (T. Trancart).

1 Tel.: + 33223185885 .
}

metabolism) and swimming activity, whereas descent to deeper waters may permit the eels to keep their average temperature below $11^{\circ} \mathrm{C}$, delaying gonadal development until reaching the Sargasso Sea. Righton et al. (2012) stated that it was unlikely that a single reason is responsible for DVMs. This strategy is more likely to involve trade-offs between temperature preference, the need to avoid predators, the need to control the onset of maturity, and energy conservation.

Whatever the reason driving DVM, this phenomenon should be considered when estimating the total energy required during silver eel migration. Firstly, DVM increases the distance of migration between coastal European inlands and the presumed Sargasso Sea spawning sites, even if it is seems negligible (about $1200 \mathrm{~m}$ per day, far below the daily swim distance, estimated to be $14 \mathrm{~km} \cdot \mathrm{day}^{-1}$ ). More importantly, rapid changes in water temperature may be costly in terms of energy expenditure, and as far as is known, the cost of transport (COT) has only been assessed at fixed temperatures (i.e. without DVMs). COT ranged from 37 to $50 \mathrm{mg} \mathrm{O} \cdot \mathrm{kg}^{-1} \cdot \mathrm{km}^{-1}$ for female European eels ranging in size from 64 to $82 \mathrm{~cm}$ (Palstra et al., 2008), and from 21 to $32 \mathrm{mg} \mathrm{O} \cdot \mathrm{kg}^{-1} \cdot \mathrm{km}^{-1}$ for schooling and isolated male European eels (mean length: $38.4+/-0.2 \mathrm{~cm}$ ) (Burgerhout et al., 2013). According to Aarestrup et al. (2009), DVMs involve daily variations in pressure and temperature, which, together with an increase in the total migration distance, are likely to affect the COT and the total energy required for migration. The effects of pressure and temperature variations were 
experimentally studied by Sebert et al. (1995), but only during the nonmigrating yellow stage of the European eel. It was found that concomitant increases in temperature and pressure increased oxygen consumption to a lesser extent than did pressure alone. Degani et al. (1989) showed a positive linear relationship between the temperature (from 18 to $27^{\circ} \mathrm{C}$ ) and oxygen consumption in European eels, but the strength of these correlations decreased according to the size of eels. Based on these preliminary observations, the present study was designed to investigate the effects of rapid changes in temperature, as observed in DVMs, on oxygen consumption in European eels.

This question appears relevant considering that silver eels stop feeding, and that their energy requirements (travel fuel and gonad maturation) during breeding migration depend exclusively on fat stored during their continental growth phase as yellow eels. Consequently, conserving energy is apparently essential and seems to contradict DVM behaviour, which is likely to increase energy requirements both to cope with temperature and pressure changes as well as to cover the extra distance.

The aim of the present study was to evaluate variations in oxygen consumption $\left(\mathrm{MO}_{2}\right)$ according to temperature variations experienced by silver eels during DVM. A DVM can be summarised by two main components that are performed simultaneously, making interpretation difficult. Firstly, a DVM indicates an ample temperature change $\left(6^{\circ} \mathrm{C}\right)$. This single temperature change could have an effect on $\mathrm{MO}_{2}$. Secondly, a DVM suggests the occurrence of thermal shock because the temperature change is very abrupt ( $30 \mathrm{~min}$ ). This could also affect the $\mathrm{MO}_{2}$.

Next, the $\mathrm{MO}_{2}$ was compared at two different temperatures, 8 and $14{ }^{\circ} \mathrm{C}$, in male and female eels. DVMs were simulated by performing an abrupt (30 min) and ample $\left(6^{\circ} \mathrm{C}\right.$ ) change in temperature, hereafter called "thermal shock". Finally, the following were compared:

- The $\mathrm{MO}_{2}$ of eels at 8 and $14{ }^{\circ} \mathrm{C}$, with or without thermal shock. These temperatures mimic the surface and deeper water temperatures, respectively, as observed by Aarestrup et al. (2009).

- The $\mathrm{MO}_{2}$ of eels, before and after mimicked DVMs.

Experimental mimicry of thermal shocks induced by DVMs was performed for both vertical migration movements, from surface to the bottom (mimicked by negative thermic shock from 8 to $14{ }^{\circ} \mathrm{C}$ ) and vice versa (positive thermic shock from 14 to $8{ }^{\circ} \mathrm{C}$ ). These data are used to discuss the impact of thermal shock on energy stores of migrating eels, and to specify the trade-off between increased energy demand and the possible benefits of DVMs during their spawning migration.

\section{Materials and methods}

\subsection{Statistical determination of design}

The number of animals was limited as much as possible to meet both statistical and ethical requirements. Consequently, we performed a preliminary power test using previous data, showing that a minimum of 18 eels ( 9 males and 9 females) allows the significant highlight of a $15 \%$ difference of respiratory metabolism between two paired-populations with a $p$-value $<0.05$.

\subsection{Fish collection and acclimation}

Eighteen silver eels ( 9 females and 9 males) were captured by traps in the Oir and Loire Rivers (Northwestern France) during their downstream migration in November 2013. Prior to measuring and tagging, fish were anaesthetized using $40 \mathrm{mg} \cdot \mathrm{L}^{-1}$ solution of Metomidate. The average eye diameter (ED, to the nearest $\mathrm{mm}$ ) and the pectoral fin length ( $\mathrm{FL}$, to the nearest $\mathrm{mm}$ ) were measured to determine their silvering stage as described by Durif et al. (2005). On this basis, all individuals were classified as active migrants (stage- 5 according to Durif et al. (2005)). The total length (TL) of females ranged from 510 to $604 \mathrm{~mm}$
( mean $=559$, sd $=29$ ) and body weight $(\mathrm{BW})$ ranged from 286 to $455 \mathrm{~g}$ (mean $=352$, $\mathrm{sd}=54$ ). The $\mathrm{TL}$ of males ranged from 346 to $409 \mathrm{~mm}$ ( mean $=382$, sd $=21$ ) and their BW from 72 to $115 \mathrm{~g}$ ( mean $=93, s d=15)$. The fish were transported to our research centre where they were acclimatised in well-aerated tanks $\left(15^{\circ} \mathrm{C}, 100 \%\right.$ air saturation). The design of the acclimatisation room was set to mimic the natural conditions that occur at the exit of estuaries, just before the beginning of the oceanic migration: $15^{\circ} \mathrm{C}$ water and an $8 \mathrm{~h}$ light: $14 \mathrm{~h}$ dark photoperiod. Next, a second acclimatisation was performed by changing the water salinity from 0 to 35 PSU over $12 \mathrm{~h}$ in individual tanks connected to an open water system with water pumped directly from the sea $\left(15^{\circ} \mathrm{C}, 100 \%\right.$ air saturation). Eels were held for 7 days until they secreted white pellets indicating their final acclimation to marine waters (Tudorache, Personal communication). In an acclimation room, light was adjusted to $10 \mathrm{~lx}$, using red light, which is few visible to eels (Pankhurst and Lythgoe, 1983), to limit stress.

\subsection{Swim-tunnel set-up and $\mathrm{O}_{2}$ consumption}

Three Blazka-type 127-l swim-tunnels designed and loaned by Leiden University (The Netherlands) and described by van den Thillart et al. (2004) were used for this experiment. The tunnels were placed in a temperature and light controlled room. An $80 \mathrm{~m}^{3}$ aerated water tank (mean water temperature $15^{\circ} \mathrm{C}+/-0.5{ }^{\circ} \mathrm{C}$ ) was used to provide oxygenated seawater ( $100 \%$ air saturation) in the swimming tunnels. Two additional water tanks $\left(1 \mathrm{~m}^{3}\right)$ were used to supply warm $\left(25^{\circ} \mathrm{C}+/-0.5^{\circ} \mathrm{C}\right)$ and cold $\left(3^{\circ} \mathrm{C}+/-0.5^{\circ} \mathrm{C}\right)$ water into the swimming tunnels. Using the closed respirometry principle (the water in the tunnels was not replaced during the oxygen decline measure), the decline in $\mathrm{O}_{2}$ level in each tunnel was measured continuously by an $\mathrm{O}_{2}$ electrode (Loligo Systems, Tjele, Denmark) when the water circuit was closed. In closed respirometry, measurements are made in a sealed chamber of known volume. The $\mathrm{O}_{2}$ concentration of the water is measured initially, then the chamber is closed and at the end of the experiment the $\mathrm{O}_{2}$ content is measured again. A disadvantage is that measurements are not made at a constant oxygen level due to the continuous use of oxygen by the animal inside the respirometer. To remove this bias, the allowed $\mathrm{O}_{2}$ decline was only $30 \%$ (from $100 \%$ to $70 \%$ air saturation). Below this value, the water was re-oxygenated. Because the re-oxygenation seemed to be very disturbing for eels, the decline of $\mathrm{O}_{2}$ was not measured thereafter and the experiment was stopped. A temperature probe in the swimming tunnels was linked to the Loligo software (WitroxView) to ensure automatic temperature adjustment. Atmospheric pressure and water salinity were set at the beginning of the recording using the acquisition software. The $\mathrm{O}_{2}$ consumption rate was calculated from the $\mathrm{O}_{2}$-concentration decline during closure. From this decline, the $\mathrm{MO}_{2}$, in $\mathrm{mg}$ of $\mathrm{O}_{2} \cdot \mathrm{kg}^{-1} \cdot \mathrm{h}^{-1}$ was calculated according to the formula:

$\mathrm{MO}_{2}=\frac{\mathrm{V} \times \Delta\left[\mathrm{O}_{2}\right]}{\mathrm{BW} \times \Delta t}$

where $\Delta\left[\mathrm{O}_{2}\right]$ is the observed $\mathrm{O}_{2}$ concentration change (in $\mathrm{mg} \mathrm{O}_{2} \cdot \mathrm{l}^{-1}$ ), $\mathrm{V}$ is the volume in the swim-tunnel (in l), BW is the body weight of the experimented eel (in $\mathrm{kg}$ ), and $\Delta t$ is the duration spent in the closure (in $\mathrm{h}$ ). To remove the technical bias associated with the electrodes (precision: $+/-0.1 \%)$, a high acquisition frequency $(1 \mathrm{~Hz})$ and moving average ( $5 \mathrm{~min}$, i.e. 300 observations by mean) of $\mathrm{O}_{2}$-concentration was used to calculate the changes.

\subsection{Experimental protocols simulating up and down DVMs}

Experiments were conducted from the 4th of November 2013 to the 20th of December 2013. Prior to the start of all experiments, $\mathrm{O}_{2}$ electrodes underwent daily calibration with sodium sulphite ( $0 \%$ air saturation) and oxygenated water (100\% air saturation). To mimic the descent 
to deeper cold waters and ascent to warmer waters, one experiment with two modalities was carried out: a decreasing thermal shock (from 14 to $8{ }^{\circ} \mathrm{C}$, Fig. 1-a) and an increasing thermal shock (from 8 to $14{ }^{\circ} \mathrm{C}$, Fig. 1-b). The eighteen silver eels ( 9 females and 9 males) were tested individually in both modalities (DVMs up and down).

\subsubsection{Modality 1 (Fig. 1-a)}

After the eel was introduced, the tunnels were filled with seawater from the main tank $\left(15^{\circ} \mathrm{C}\right)$ and the light was turned off to ensure total darkness. The water temperature in the tunnels was slowly set to the initial target temperature $\left(14^{\circ} \mathrm{C}\right)$. Eels started to swim at a speed of 0.4 body length $\cdot \mathrm{s}^{-1}$, which was maintained for $4 \mathrm{~h}$. This swimming speed is the minimal estimated speed required to reach the Sargasso Sea in time for spawning (Palstra et al., 2008). The 4 h delay before starting experiments corresponds to the maximum duration required to remove the stress effect on $\mathrm{MO}_{2}$, which is potentially induced by the handling and transfer of eels into tunnels. This recovery time was determined in preliminary experiments using the same eels and applying identical experimental conditions. After the $4 \mathrm{~h}$ recovery time, the oxygen concentration was recorded over $1 \mathrm{~h}$ to give the baseline $\mathrm{MO}_{2}$
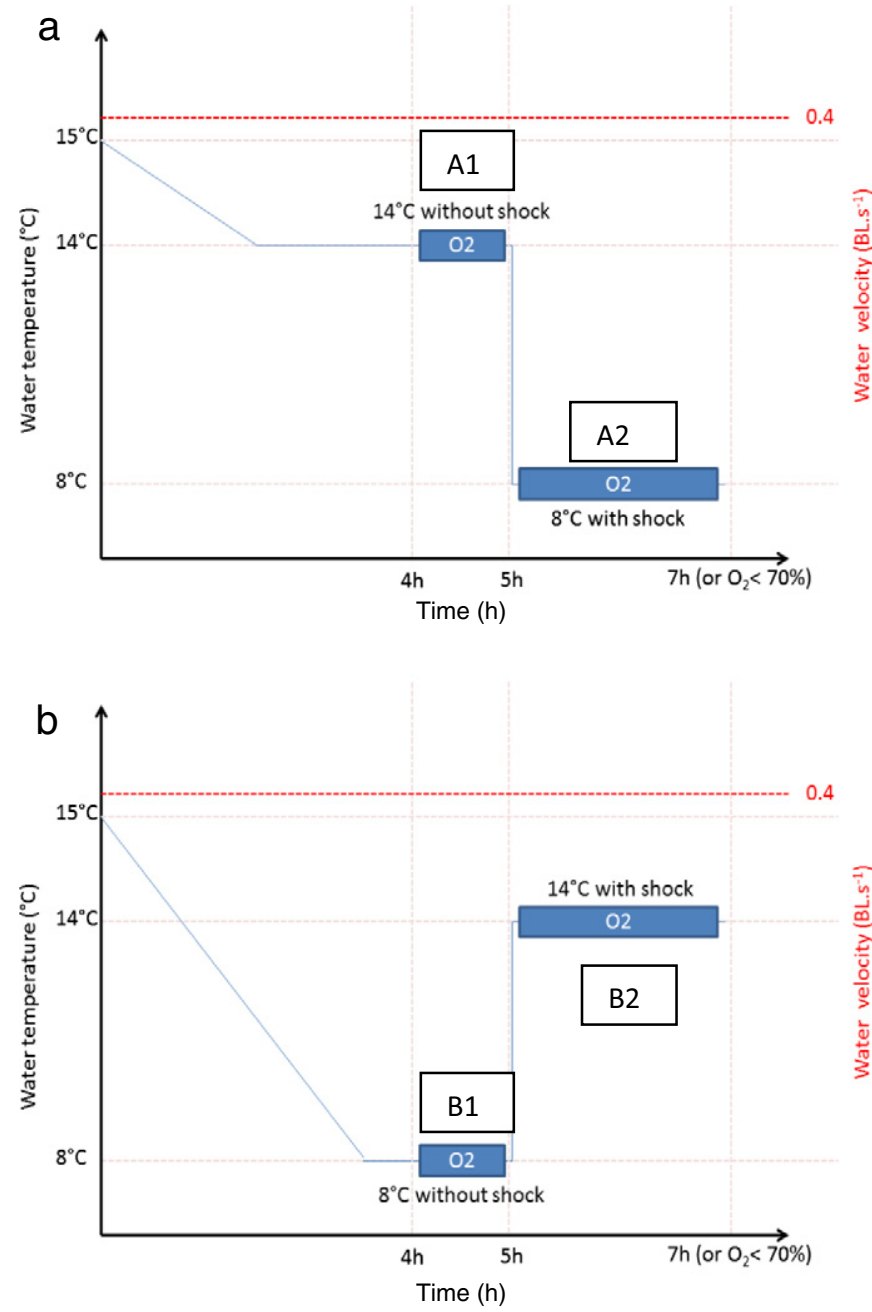

Fig. 1. Experimental design showing the temperature variation used in experiments on silver eels according to two modalities: Decreasing (a) and increasing (b) thermal shocks. Blue lines are the instantaneous water temperatures in tunnels. Red lines are water velocities in body length per second. Blue squares represent durations of oxygen decline logging. To increase the readability, we call A1 and A2 the mean oxygen consumption during the first modality of the experiment (DVMs down), and B1 and B2 the mean oxygen consumption during the second modality of the experiment (DVMs up). at $14{ }^{\circ} \mathrm{C}$ (called A1) without thermal shock. The thermal shock was then carried out using the cold tank, over 30 min, adjusting the water temperature from 14 to $8{ }^{\circ} \mathrm{C}$. Immediately after the 30 min shock period, the level of oxygen saturation was recorded over $2 \mathrm{~h}$ to give the $\mathrm{MO}_{2}$ at $8{ }^{\circ} \mathrm{C}$ (called A2) with thermal shocks.

\subsubsection{Modality 2 (Fig. 1 -b)}

This experiment was performed carefully to ensure consistency with modality 1 , with the exception of the temperatures. In this experiment, the initial target temperature was $8^{\circ} \mathrm{C}$. After the 4-h recovery time, the oxygen concentration was recorded over $1 \mathrm{~h}$ to give the $\mathrm{MO}_{2}$ at $8{ }^{\circ} \mathrm{C}$ (called B1) without thermal shock. Thermal shock was then performed using the hot tank for $30 \mathrm{~min}$, increasing the temperature from 8 to $14{ }^{\circ} \mathrm{C}$. Immediately after heat shock, the oxygen saturation level was again recorded over $2 \mathrm{~h}$ to give the oxygen consumption at $14{ }^{\circ} \mathrm{C}$ (called B2) with thermal shock.

\subsection{Statistics}

Data from these two modalities were used to detect correlations at three different levels.

Firstly, the influence of temperature on eel metabolism was analysed by testing the difference between $\mathrm{MO}_{2}$ at $8{ }^{\circ} \mathrm{C}$ (A1) and $14{ }^{\circ} \mathrm{C}(\mathrm{B} 1)$ for each sex using a one-tailed paired Student's $t$-test.

Secondly, the effect of thermal shock on $\mathrm{MO}_{2}$ was analysed. To this end, the $\mathrm{MO}_{2}$ was compared at the same temperatures $\left(8{ }^{\circ} \mathrm{C}\right.$ and $14{ }^{\circ} \mathrm{C}$ ), with and without thermal shock, using a two-tailed paired Student's $t$-test (A1 vs B2 and A2 vs B1).

Finally, the association between these two factors was analysed. A two-tailed paired Student's $t$-test was used to assess the statistical association between the $\mathrm{MO}_{2}$ at $8{ }^{\circ} \mathrm{C}$ without shock (B1) and at $14{ }^{\circ} \mathrm{C}$ with shock (B2), mimicking an ascending vertical movement, and between the $\mathrm{MO}_{2}$ at $14{ }^{\circ} \mathrm{C}$ without shock (A2) and the $\mathrm{MO}_{2}$ at $8{ }^{\circ} \mathrm{C}$ with shock (A1), mimicking a descending vertical movement.

For each paired $t$-test, the normality of distribution of difference between the two modalities was checked visually. The $t$-tests were fitted using the $t$-test function in the R language/environment ( $\mathrm{R}$ Development Core Team, 2011).

\section{Results}

Occasionally, not all of the male eels swam in the tunnels; therefore, the number of fish in each modality was slightly reduced. When modified, the real number of fish was included. All the results are presented in Table 1 for females and in Table 2 for males.

\subsection{Effect of temperature on silver eel metabolism without thermal shock}

There was no significant difference between $\mathrm{MO}_{2}$ at $14^{\circ} \mathrm{C}$ and $8{ }^{\circ} \mathrm{C}$ in female silver eels (Table $1, \mathrm{~A} 1 \mathrm{vs} \mathrm{B} 1, p=0.51$ ). $\mathrm{MO}_{2}$ was $24 \%$ higher at $14{ }^{\circ} \mathrm{C}$ than at $8{ }^{\circ} \mathrm{C}$ for male silver eels (Table 2, A1 vs B1, $p=0.09$ ).

\subsection{Effect of thermal shock on muscle $\mathrm{O}_{2}$-consumption in silver eels}

In females, the $\mathrm{MO}_{2}$ was $17.9 \%$ higher at $8{ }^{\circ} \mathrm{C}$ with shock than without shock (Table 1 , B1 vs A2, $p=0.10$ ). The $\mathrm{MO}_{2}$ was $16.0 \%$ higher at $14{ }^{\circ} \mathrm{C}$ with shock than without shock (Table $1, \mathrm{~A} 1$ vs B2, $p=0.03$ ).

In males, the $\mathrm{MO}_{2}$ was $36.3 \%$ higher at $8{ }^{\circ} \mathrm{C}$ with shock than without shock (Table 2, B1 vs A2, $p=0.05$ ). The $\mathrm{MO}_{2}$ was $39.9 \%$ higher at $14{ }^{\circ} \mathrm{C}$ with shock than without shock (Table $2, \mathrm{~A} 1 \mathrm{vs} \mathrm{B} 2, p=0.03$ ).

\subsection{Cumulative effect on various temperatures and thermal shock on $\mathrm{MO}_{2}$} by silver eels

At a stable temperature of $14{ }^{\circ} \mathrm{C}$ (A1 in Tables 1 and 2), corresponding to the nocturnal migration at shallower depths, female eels 
Table 1

Experimental design and $t$-test values for female silver eels. The mean $\mathrm{MO}_{2}$ (mean) and standard deviation (sd) are given in $\mathrm{mg} \mathrm{O}_{2} \cdot \mathrm{kg}^{-1} \cdot \mathrm{h}^{-1}$.

\begin{tabular}{|c|c|c|c|c|c|}
\hline Modality & & DVM down & & & \\
\hline & $\begin{array}{l}\text { Target } \\
\text { temperature } \\
\left({ }^{\circ} \mathrm{C}\right)\end{array}$ & $\begin{array}{l}\text { Thermal } \\
\text { shock effect }\end{array}$ & $\begin{array}{l}\text { Mean } 0_{2} \\
\text { consumption }\end{array}$ & $\begin{array}{l}\mathrm{Sd} \mathrm{O}_{2} \\
\text { consumption }\end{array}$ & $\mathrm{N}$ \\
\hline A1 & 14 & No & 76.71 & 9.22 & 9 \\
\hline $\mathrm{A} 2$ & 8 & Yes & 90.42 & 22.19 & 9 \\
\hline \multirow{2}{*}{$\begin{array}{l}\text { Modality } \\
2\end{array}$} & & \multicolumn{4}{|l|}{ DVM up } \\
\hline & $\begin{array}{l}\text { Target } \\
\text { temperature } \\
\left({ }^{\circ} \mathrm{C}\right)\end{array}$ & $\begin{array}{l}\text { Thermal } \\
\text { shock effect }\end{array}$ & $\begin{array}{l}\text { Mean } \mathrm{O}_{2} \\
\text { consumption }\end{array}$ & $\begin{array}{l}\mathrm{Sd} \mathrm{O}_{2} \\
\text { consumption }\end{array}$ & $\mathrm{n}$ \\
\hline B1 & 8 & No & 76.72 & 34.41 & 9 \\
\hline \multirow[t]{2}{*}{ B2 } & 14 & Yes & 89.02 & 16.54 & 9 \\
\hline & \multicolumn{4}{|c|}{ Paired modalities } & $p$-values \\
\hline \multirow[t]{5}{*}{ t-test } & \multicolumn{3}{|c|}{$14{ }^{\circ} \mathrm{C}$ vs $8{ }^{\circ} \mathrm{C}-$ no shock } & $\mathrm{p}(\mathrm{A} 1$ vs $\mathrm{B} 1)$ & 0.51 \\
\hline & \multicolumn{3}{|c|}{$14{ }^{\circ} \mathrm{C}$ - without/with shock } & $\mathrm{p}(\mathrm{A} 1$ vs $\mathrm{B} 2)$ & 0.03 \\
\hline & \multicolumn{3}{|c|}{$8{ }^{\circ} \mathrm{C}-$ without/with shock } & $\mathrm{p}(\mathrm{B} 1$ vs $\mathrm{A} 2)$ & 0.10 \\
\hline & \multicolumn{3}{|l|}{ DVM down } & $\mathrm{p}(\mathrm{A} 1$ vs $\mathrm{A} 2)$ & 0.05 \\
\hline & \multicolumn{3}{|l|}{ DVM up } & $\mathrm{p}(\mathrm{B} 1 \mathrm{vs} \mathrm{B} 2)$ & 0.13 \\
\hline
\end{tabular}

consumed a mean of $76.71 \mathrm{mg} \mathrm{O} 2 \cdot \mathrm{kg}^{-1} \cdot \mathrm{h}^{-1}(\mathrm{sd}=9.22)$ and males consumed a mean of $110.38 \mathrm{mg} \mathrm{O}_{2} \cdot \mathrm{kg}^{-1} \cdot \mathrm{h}^{-1}(\mathrm{sd}=47.42)$. During descending migration, simulated by thermal shock experiments $\left(14{ }^{\circ} \mathrm{C}\right.$ to $8{ }^{\circ} \mathrm{C}$, A2 in Tables 1 and 2), the $\mathrm{O}_{2}$ consumption significantly $(p=0.049)$ increased by $17.87 \%$ (from 76.71 to $90.42 \mathrm{mg} \mathrm{O} \cdot \mathrm{kg}^{-1} \cdot \mathrm{h}^{-1}$ ) in females (Table 1). The $\mathrm{O}_{2}$ consumption increased by $9.69 \%$ in males (from 110.38 to $121.08 \mathrm{mg} \mathrm{O}_{2} \cdot \mathrm{kg}^{-1} \cdot \mathrm{h}^{-1}$ ), although this increase was not significant ( $p=0.32$, Table 2 ).

At a stable cold temperature of $8{ }^{\circ} \mathrm{C}$ (B1 in Tables 1 and 2), corresponding to diurnal migration at deep depths, the mean oxygen consumption was $76.72 \mathrm{mg} \mathrm{O} \cdot \mathrm{kg}^{-1} \cdot \mathrm{h}^{-1}(\mathrm{sd}=34.41)$ for females and $88.84 \mathrm{mg} \mathrm{O} \cdot \mathrm{kg}^{-1} \cdot \mathrm{h}^{-1}(\mathrm{sd}=45.86)$ for males (Tables 1 and 2$)$. Ascent from cold (deep) to warm (surface) water was simulated in the ascent shock experiments $\left(8^{\circ} \mathrm{C}\right.$ to $14{ }^{\circ} \mathrm{C}, \mathrm{B} 2$ in Tables 1 and 2$)$, which induced an increase in $\mathrm{MO}_{2}$ of $16.03 \%$ (from 76.72 to $89.02 \mathrm{mg} \mathrm{O} \cdot \mathrm{kg}^{-1} \cdot \mathrm{h}^{-1}$ ) in females and of $73.90 \%$ (from 88.84 to $154.54 \mathrm{mg} \mathrm{O} 2 \cdot \mathrm{kg}^{-1} \cdot \mathrm{h}^{-1}$ ) in males

Table 2

Experimental and $t$-test values for male silver eels. The mean $\mathrm{MO}_{2}$ (mean) and standard deviation (sd) are given in $\mathrm{mg} \mathrm{O}_{2} \cdot \mathrm{kg}^{-1} \cdot \mathrm{h}^{-1}$.

\begin{tabular}{|c|c|c|c|c|c|}
\hline Modality & & DVM down & & & \\
\hline & $\begin{array}{l}\text { Target } \\
\text { temperature } \\
\left({ }^{\circ} \mathrm{C}\right)\end{array}$ & $\begin{array}{l}\text { Thermal } \\
\text { shock effect }\end{array}$ & $\begin{array}{l}\text { Mean } \mathrm{O}_{2} \\
\text { consumption }\end{array}$ & $\begin{array}{l}\mathrm{Sd} \mathrm{O}_{2} \\
\text { consumption }\end{array}$ & $\mathrm{n}$ \\
\hline $\mathrm{A} 1$ & 14 & No & 110.38 & 47.42 & 7 \\
\hline $\mathrm{A} 2$ & 8 & Yes & 121.08 & 58.97 & 5 \\
\hline \multirow{2}{*}{$\begin{array}{l}\text { Modality } \\
2\end{array}$} & & \multicolumn{4}{|l|}{ DVM up } \\
\hline & $\begin{array}{l}\text { Target } \\
\text { temperature } \\
\left({ }^{\circ} \mathrm{C}\right)\end{array}$ & $\begin{array}{l}\text { Thermal } \\
\text { shock effect }\end{array}$ & $\begin{array}{l}\text { Mean } \mathrm{O}_{2} \\
\text { consumption }\end{array}$ & $\begin{array}{l}\mathrm{Sd} \mathrm{O}_{2} \\
\text { consumption }\end{array}$ & $\mathrm{n}$ \\
\hline B1 & 8 & No & 88.84 & 45.86 & 5 \\
\hline \multirow[t]{2}{*}{ B2 } & 14 & Yes & 154.54 & 61.09 & 7 \\
\hline & \multicolumn{4}{|c|}{ Paired modalities } & $p$-values \\
\hline \multirow[t]{5}{*}{ t-test } & \multicolumn{3}{|c|}{$14{ }^{\circ} \mathrm{C}$ vs $8{ }^{\circ} \mathrm{C}-$ no shock } & $\mathrm{p}(\mathrm{A} 1 \mathrm{vs} \mathrm{B} 1)$ & 0.09 \\
\hline & \multicolumn{3}{|c|}{$14^{\circ} \mathrm{C}$ - without/with shock } & $\mathrm{p}(\mathrm{A} 1 \mathrm{vs} \mathrm{B} 2)$ & 0.03 \\
\hline & \multicolumn{3}{|c|}{$8^{\circ} \mathrm{C}$ - without/with shock } & $\mathrm{p}(\mathrm{B} 1$ vs $\mathrm{A} 2)$ & 0.05 \\
\hline & \multicolumn{3}{|l|}{ DVM down } & $\mathrm{p}(\mathrm{A} 1 \mathrm{vs} \mathrm{A} 2)$ & 0.32 \\
\hline & \multicolumn{3}{|l|}{ DVM up } & $\mathrm{p}(\mathrm{B} 1$ vs B2) & 0.004 \\
\hline
\end{tabular}

(Tables $1 \& 2$ ). These differences were significant in males only $(p=0.004)$.

\section{Discussion}

\subsection{Effect of single thermal shock on the respiratory metabolism of eels}

The results from the present study suggest that there was a significant difference between the $\mathrm{MO}_{2}$ at a given temperature $\left(14{ }^{\circ} \mathrm{C}\right.$ and 8 ${ }^{\circ} \mathrm{C}$ ) without and with thermal shock (A1 vs B2, and B1 vs A2). This indicates that a single thermal shock, as observed in field studies during DVMs, has a high energy-requirement, since the $\mathrm{MO}_{2}$ at $8{ }^{\circ} \mathrm{C}$ and $14{ }^{\circ} \mathrm{C}$ after a thermal shock was increased by $36.31 \%$ and $39.94 \%$, respectively, for males, and $17.85 \%$ and $16.04 \%$, respectively, for females than after a slow change in temperature. These data were obtained by measurements made during $120 \mathrm{~min}$ after the thermal shock. The duration chosen was very important. Indeed, $\mathrm{MO}_{2}$ was higher just after the thermal shock, at about $30 \mathrm{~min}$. There was a smaller difference when a $120 \mathrm{~min}$ period was used, thus suggesting that the impacts of the thermal shocks were long-lasting. Nevertheless the real duration of the $\mathrm{MO}_{2}$ increase remained unable to estimate with such an experimental device. Consequently, these results have to be considered as a lower bound of the integration of the varying $\mathrm{MO}_{2}$.

\subsection{Diel vertical migrations in Anguilla spp}

DVMs were firstly highlighted in European eels in 1989 by Tesch (1989) and in A. dieffenbachii in 2005 by Jellyman and Tsukamoto (2005). In their field study, Aarestrup et al. (2009) tracked eels with pop-up satellite archival transmitters and showed clear and regular DVMs predominantly between depths of $200 \mathrm{~m}$ and $1000 \mathrm{~m}$. During the night, eels remained in the shallower warmer water, and at dawn they made a steep dive down to the cool disphotic zone. At night, they ascended sharply back to the upper layer.

DVMs seem to be usual in eels since Manabe et al. (2011) recently showed that two Japanese eels, A. japonica, which were tracked with pop-up tags for about a month also showed clear DVMs, predominantly swimming between depths of $100-500 \mathrm{~m}$ at night and $500-800 \mathrm{~m}$ in the day. DVMs were also observed for three New Zealand longfin eels, A. dieffenbachii, tracked by pop-up tags in May 2006 (Jellyman and Tsukamoto, 2010). In their survey, the three eels exhibited daytime dives to depths of $600-900 \mathrm{~m}$ in $6-7^{\circ} \mathrm{C}$ waters, followed by night ascents to depths of $200-300 \mathrm{~m}$ in $16-17^{\circ} \mathrm{C}$ waters. This pattern is consistent with that observed in European eels by Aarestrup et al. (2009).

These studies all suggest that regular exposure to cool temperatures is used by eels to regulate the rate of gonad maturity that is thermaldependent. While swimming at depth could reduce predation, the increased pressure would also stimulate ovarian development, which may also be controlled by regular ascents to shallower waters.

Complementary hypotheses have also been used to explain DVM behaviour. These suggest that there is a trade-off between predator avoidance and the necessity to maintain a high metabolism that is sufficient for migration in three species of tropical Pacific eels (A. marmorata, A. megastoma, and A. obscura). These species exhibit DVMs from around $200 \mathrm{~m}$ night time depth, to $320 \mathrm{~m}$ (A. obscura), $650 \mathrm{~m}$ (A. marmorata), and $750 \mathrm{~m}$ (A. megastoma) during the day (Schabetsberger et al., 2013). Such alternative hypotheses were also proposed by Jellyman and Tsukamoto (2005) after a study based on 10 female longfin eels (A. australis) tracked in May 2001.

The only way to observe DVMs in field studies is to use pop-up tags, which are too heavy to be used on males (whom are always smaller), meaning that this approach is limited in its application to large female eels only. In the present study, for the first time, male eels were experimentally submitted to thermic conditions comparable to those observed during DVMs. To date, whether or not males perform DVMs 
during migration remains unknown, but the results from this study suggest that DVMs may require more energy in males than in females.

In the present study, the effect of mimicked DVMs was different according to the sex of the eels. Female eels were only affected by DVMs during the descent, while male eels were affected during the ascent. In female eels, a difference before and after the DVM ascent was observed ( $76.72 \mathrm{vs} 89.02 \mathrm{mg} \cdot \mathrm{O}_{2} / \mathrm{kg}^{-1} \cdot \mathrm{h}^{-1}$ ), but this difference was not significant. However, this result should be carefully interpreted, because there was high variability in the $\mathrm{B} 2 \mathrm{MO}_{2}$ (mean $=76.72$, sd $=34.41$ ), which probably invalidated the statistic test. In male eels, there was no difference between $\mathrm{MO}_{2}$ before and after the DVM descent ( $p=$ 0.32 ). Again, strong variability in the oxygen consumption could have affected the statistical test. However, Degani et al. (1989) showed that oxygen uptake in the European eel was higher at $27^{\circ} \mathrm{C}$ than at $18{ }^{\circ} \mathrm{C}$. They also showed that the effect of temperature was greater on smaller eels than on larger eels. The present results are consistent with those from this previous study because only the $\mathrm{MO}_{2}$ of males was impacted by the effect of temperature alone ( $p$ (A1 vs B1) $=0.09$ for males and 0.51 for females). Therefore, it can reasonably be assumed that the difference before and after the DVM descent in male eels was masked by the effect of temperature alone on oxygen uptake, suggesting that the DVM descent is easier than the DVM ascent.

The present study suggests that DVMs require a strong energy expenditure indicating that there must be some significant hidden gain for the eels as a trade-off for this energy loss; however, the duration of this increase requires further exploration. Because the energy expenditure is taken from energy stored for the migration, it is suggested that this benefit is most likely for reproduction. Thus, whether or not reproduction in the absence of DVMs is possible remains unknown.

\subsection{Direct impact of DVMs on total energy required for migration and COT}

According to a study by Aarestrup et al. (2009), one can estimate that DVMs add an additional distance of $1.2 \mathrm{~km}$ per day to the daily migratory distance ( $14 \mathrm{~km}$ per day, estimated by GPS data), leading to a $10 \%$ increase. However the authors assumed that the drag of the mark has an influence on this low distance swam per day. Indeed, an experimental study showed that European silver eels have an average swimming speed of 0.5 body length per second, enabling $80 \mathrm{~cm}$ silver eels to swim the 5000 or $6000 \mathrm{~km}$ migration in about 6 months (van den Thillart et al., 2004), leading to a 30-35 km per day swimming speed. According to this speed, which appears more realistic, the distance increase induced by DVM reach only about $4 \%$. Indeed, this first component of DVMs increases the total energy required for migration by increasing the total distance. Palstra et al. (2008), showed that the COT during migration in wild European silver eels ranged from 37 to $50 \mathrm{mg} \mathrm{O} \mathrm{O}_{2} \cdot \mathrm{kg}^{-1} \cdot \mathrm{km}^{-1}$ for females. With the mean data of eels studied here (352 g), and based only on distance increase due to DVMs (200 km according to van den Thillart et al. (2004)), the data of Palstra et al. indicates a supplementary loss ranging from 2.6 to $3.5 \mathrm{~g}$ of lipids due to DVMs, in comparison to a migration without DVMs, which seems relatively low.

However, above the effect of increased total distance, the present study suggests that the thermal shock experienced during DVMs increases oxygen consumption. By comparison with a migration at a constant temperature $\left(8\right.$ or $\left.14^{\circ} \mathrm{C}\right)$, a migration at variable temperatures, from 8 to $14{ }^{\circ} \mathrm{C}$ and from 14 to $8{ }^{\circ} \mathrm{C}$, has greater energy requirements.
Nevertheless, these data and those from previous studies suggest that the temperature variations only influence the $\mathrm{MO}_{2}$ in small eels (including males). The females (larger than males) seem to be less affected by the direction of the DVMs than males.

However, this extra consumption requires further studies because this experimental design does not permit the inclusion of pressure, another fundamental change experienced by silver eels during DVMs. Other factors may also influence $\mathrm{MO}_{2}$, such as light condition because DVMs seem to follow a circadian rhythm, which could be analysed in further experiments. In a previous study, authors showed that marine birds showed different behaviours related to a strong stress (diving) if this stress was voluntary or forced (Kanwisher et al., 1981). Unfortunately, it is not possible to distinguish between a temperature effect and a general effect of stress in an experimental study using fish. By definition, it is a fundamental limit of experimental studies. We cannot exclude the possibility that the observed responses would differ based on individual fish behaviours. This clearly opens up new research directions to enable a better understanding of the effect that this intriguing DVM behaviour has on the physiology of anguillid eels.

\section{References}

Aarestrup, K., Økland, F., Hansen, M.M., Righton, D., Gargan, P., Castonguay, M., Bernatchez, L., Howey, P., Sparholt, H., Pedersen, M.I., McKinley, R.S., 2009. Oceanic spawning migration of the European Eel (Anguilla anguilla). Science 325 (5948), 1660

Burgerhout, E., Tudorache, C., Brittijn, S.A., Palstra, A.P., Dirks, R.P., van den Thillart, G.E.E.J.M., 2013. Schooling reduces energy consumption in swimming male European eels, Anguilla anguilla L. J. Exp. Mar. Biol. Ecol. 448, 66-71.

Degani, G., Gallagher, M.L., Meltzer, A., 1989. The influence of body size and temperature on oxygen-consumption of the European eel, Anguilla anguilla. J. Fish Biol. 34 (1), 19-24.

Durif, C., Dufour, S., Elie, P., 2005. The silvering process of Anguilla anguilla: a new classification from the yellow resident to the silver migrating stage. J. Fish Biol. 66, 1-19.

Jellyman, D., Tsukamoto, K., 2005. Swimming depths of the offshore migrating longfin eels Anguilla dieffenbachii. Mar. Ecol. Prog. Ser. 286, 261-267.

Jellyman, D., Tsukamoto, K., 2010. Vertical migrations may control maturation in migrating female Anguilla dieffenbachii. Mar. Ecol. Prog. Ser. 404, 241-247.

Kanwisher, J.W., Gabrielsen, G., Kanwisher, N., 1981. Free and forced diving in birds. Science 211 (4483), 717-719.

Manabe, R., Aoyama, J., Watanabe, K., Kawai, M., Miller, M.J., Tsukamoto, K., 2011. First observations of the oceanic migration of Japanese eel, from pop-up archival transmitting tags. Mar. Ecol. Prog. Ser. 437, 229-240.

Palstra, A., van Ginneken, V., van den Thillart, G., 2008. Cost of transport and optimal swimming speed in farmed and wild European silver eels (Anguilla anguilla). Comp. Biochem. Physiol. A Mol. Integr. Physiol. 151 (1), 37-44.

Pankhurst, N.W., Lythgoe, J.N., 1983. Changes in vision and olfaction during sexual maturation in the European eel Anguilla anguilla (L.). J. Fish Biol. 23 (2), 229-240.

R Development Core Team, 2011. R: A Language and Environment for Statistical Computing, Vienna, Austria.

Righton, D., Aarestrup, K., Jellyman, D., Sebert, P., van den Thillart, G., Tsukamoto, K., 2012 The Anguilla spp. migration problem: 40 million years of evolution and two millennia of speculation. J. Fish Biol. 81 (2), 365-386.

Schabetsberger, R., Økland, F., Aarestrup, K., Kalfatak, D., Sichrowsky, U., Tambets, M., Dall'Olmo, G., Kaiser, R., Miller, P., 2013. Oceanic migration behaviour of tropical Pacific eels from Vanuatu. Mar. Ecol. Prog. Ser. 475, 177-190.

Sebert, P., Simon, B., Barthelemy, L., 1995. Effects of a temperature increase on oxygenconsumption of yellow fresh-water eels exposed to high hydrostatic-pressure. Exp. Physiol. 80 (6), 1039-1046.

Tesch, F.W., 1977. The Eel. Chapman and Hall, London (434 pp.)

Tesch, F.-W., 1989. Changes in swimming depth and direction of silver eels (Anguilla anguilla L.) from the continental shelf to the deep sea. Aquat. Living Resour. 2 (01), 9-20.

van den Thillart, G., van Ginneken, V., Körner, F., Heijmans, R., van der Linden, R., Gluvers, A., 2004. Endurance swimming of European eel. J. Fish Biol. 65, 312-318.

Wahlberg, M., Westerberg, H., Aarestrup, K., Feunteun, E. Gargan, P., Righton, D., 2014. Evidence of marine mammal predation of the European eel (Anguilla anguilla L.) on its marine migration. Deep-Sea Res. I Oceanogr. Res. Pap. 86, 32-38 [RH] 